\title{
Composition variation in essential oils of Artemisia nilagirica and Artemisia capillaris, growing in India
}

\author{
Ruchi Badoni, Deepak Kumar Semwal* and Usha Rawat \\ Department of Chemistry, H.N.B. Garhwal University, Srinagar-246174 (Uttarakhand), INDIA \\ * Corresponding author. E-mail: dr_dks.1983@yahoo.co.in
}

\begin{abstract}
The present study was aimed to find out the chemical constituents of essential oils of Artemisia nilagirica (Clarke) Pamp. and Artemisia capillaris Thunb. of Asteraceae family, growing in Garhwal region of India. The essential oils were obtained by hydro-distillation and subjected to detailed GC-MS analysis in order to determine the variation in their volatile constituents. While comparing the common constituents in both of the species, the remarkable variation was observed and it was $6.03,3.251,2.093,33.73,7.573,15.041$ and $8.00 \%$ for transcaryophyllene, DL-limonene, á-pinene, á-thujone, â-myrcene, â-ocimene and â-thujone, respectively.
\end{abstract}

Keywords: Artemisia nilagirica, Artemisia capillaris, Asteraceae, Essential oils, â-Ocimene, DL-Limonene

\section{INTRODUCTION}

The essential oils are concentrated, hydrophobic liquid containing volatile aroma compounds from plants, which are called aromatic herbs or aromatic plants. They are also known as volatile or ethereal oils, or simply as the oil of the plant from which they are derived, such as camphor oil, peppermint oil, lemon-grass oil, etc. Essential oils have played an important role in human life, so much so that they have become indispensable in the production of perfumes, cosmetics, medicines, food preparation and as a starting material for the synthesis of various other compounds.

About 8000 flowering plant species grow in Western Himalaya be rich in genetic diversity of medicinal and aromatic plants (Rao, 1994). Among these, most of the plants possess very refined and pleasant smell which can be utilized in flavor and perfumery. Majority of these plants are used for various ailments as traditional medicines. Various perfumeries, flavor and fragrance industries produce their required products from these plant species for commercial purposes.

Artemisia nilagirica (Asteraceae) vern. Kunja is a much branched herb or undershrub. The leaf juice of plant is used against the intestinal worms whereas Artemisia capillaris (Asteraceae) vern. Jhirun is an annual glabrous or sparsely and hairy herb; decoction of the leaves has been taken as a bitter tonic for worms and colic (Gaur, 1999). A. capillaris has long been used in China and Japan to treat jaundice (Okuno et al., 1981). The plants of Artemisia are widely distributed and well known for their essential oil bearing properties. Numerous reports have been published on essential oils composition of different Artemisia species, especially on those used in flavor ISSN : 0974-9411 All Rights Reserved ๑ Applied and Natural Science Foundation www.ansfoundation.org industries and in medication commercially (Gilemeister and Hoffman, 1961; Juteau et al., 2002; Saleh et al., 2006; Cetin et al., 2009; Jaime A. Teixeira da Silva, 2004 and Ramezani et al., 2005). Since these plants have their medicinal values, the present study was aimed to find out the compositional variation of $A$. capillaris and $A$. nilagirica, frequently used in traditional medicines in India.

\section{MATERIALS AND METHODS}

Plant materials: The aerial parts of A. nilagirica were supplied by Indian Glycol Limited, Ghimtoli, Dist. Rudraprayag, Uttarakhand, whereas A. capillaris was collected from Garhwal University campus, Chauras, Dist. Tehri Garhwal, during the month of June. The plants were identified from Taxonomy Laboratory, Department of Botany, University of Garhwal, Srinagar and the voucher specimens (GUH-2209 and GUH-6391, respectively) of the plants were deposited in departmental herbarium for future records.

Oil isolation procedure: The essential oil from fresh parts of plants species were isolated by hydro-distillation method, using a Clevenger apparatus. The distilled oils were dried over anhydrous sodium sulfate and stored in tightly closed dark vials at $4{ }^{\circ} \mathrm{C}$ until the analysis and tests has been carried out. The constituents present in the essential oils were further analyzed by GC-MS.

GC-MS analysis: The identification of chemical constituents was carried out by the GC/MS. The analysis was performed with GC Perkin-Elmer-Clarus-500 plus MS Perkin-Elmer-Clarus-500; Column: Perkin-Elmer HP 5-MS (oven: initial temp. $50^{\circ} \mathrm{C}$ for $5 \mathrm{~min}$, ramp $3^{\circ} \mathrm{C} / \mathrm{min}$ to 220 ${ }^{\circ} \mathrm{C}$ per min; inj $=270{ }^{\circ} \mathrm{C}$; volume $=1$ ìl; split ratio $=1: 100$; 
Table 1. Chemical composition of essential oils of A. nilagirica and A. capillaris.

\begin{tabular}{|c|c|c|c|}
\hline S. No. & Constituents & $\begin{array}{c}\text { A. nilagirica } \\
(\%)\end{array}$ & $\begin{array}{c}\text { A. capillarys } \\
(\%)\end{array}$ \\
\hline 1 & 1,1-Biphenyl & - & 42.055 \\
\hline 2 & 1,8-Cineole & 1.266 & 0.523 \\
\hline 3 & 1-Borneol & 4.760 & - \\
\hline 4 & $\begin{array}{l}\text { 1-Cyclohexene-1 } \\
\text {-carboxaldehyde }\end{array}$ & 1.107 & - \\
\hline 5 & $\begin{array}{l}\text { 1-Phenyl-penta-2, } \\
\text { 4-dyne }\end{array}$ & - & 1.073 \\
\hline 6 & 4-Terpineol & 7.059 & - \\
\hline 7 & DL-Limonene & 2.694 & 5.365 \\
\hline 8 & Germacrene D & 1.087 & - \\
\hline 9 & Lavandulyl acetate & 2.850 & - \\
\hline 10 & p-Menth-1-en-8-ol & 1.571 & - \\
\hline 11 & Sabinene & 3.081 & - \\
\hline 12 & Trans-caryophyllene & 1.505 & 7.535 \\
\hline 13 & Trans-ocimene & 0.166 & 1.585 \\
\hline 14 & Umbellulone & 1.991 & - \\
\hline 15 & $\alpha$-Pinene & 0.233 & 2.326 \\
\hline 16 & $\alpha$-Terpinene & 1.555 & - \\
\hline 17 & $\alpha$-Terpinolene & - & 1.188 \\
\hline 18 & $\alpha$-Thujone & 36.944 & 3.214 \\
\hline 19 & $\beta$-Eudesmol & 1.887 & - \\
\hline 20 & $\beta$-Myrcene & 1.664 & 9.237 \\
\hline 21 & $\beta$-Ocimene & 0.762 & 15.803 \\
\hline 22 & $\beta$-Pinene & 0.114 & 0.643 \\
\hline 23 & $\beta$-Sesquiphellendrene & 1.585 & - \\
\hline 24 & $\beta$-Thujone & 8.213 & 0.213 \\
\hline 25 & $\gamma$-Curcumene & 1.302 & - \\
\hline 26 & $\gamma$-Elemene & - & 0.728 \\
\hline 27 & $\gamma$-Terpinene & 2.717 & 5.307 \\
\hline
\end{tabular}

carrier gas $=\mathrm{He}$; solvent delay $=5 \mathrm{~min} ;$ transfer temp $=250$ ${ }^{\circ} \mathrm{C}$; source temp $=180{ }^{\circ} \mathrm{C}$; column $=60 \mathrm{~m} \times 250 \mathrm{~mm}$. The constituents were identified by compared the MS with standard compounds of Nist and Willey libraries. The area percentage of chemical constituents from both species is given in Table 1.

\section{RESULTS AND DISCUSSION}

The essential oils of the selected plant species were subjected to detailed GC-MS analysis in order to determine the variations in their volatile constituents. The results based on the comparison on essential oil constituents of $A$. nilagirica and $A$. capillaris are summarized in Table 1. The major constituents of $A$. nilagirica were á-thujone (36.944\%), â-thujone (8.213\%), 4-terpeneol $(7.059 \%)$ and 1-boroneol (4.764\%) whereas, the major constituents of $A$. capillaris were 1, 1-biphenyl (42.055\%), â-ocimene (15.803\%), â-myrecene (9.237\%), trans-caryophyllene ( $7.535 \%)$, limonene $(5.365 \%)$. These major constituents of both the species are either absent or negligible in other (Table 1). The constituent 1,8cineole, DL-limonene, trans-caryophyllene, transocimene, á-pinene, á-thujone, â-myrcene, â-ocimene, âpinene, $\hat{a}$-thujone, ã-terpinene has been found common in both the plants species but the major variations were observed in trans-caryophyllene, DL-limonene, á-pinene, á-thujone, â-myrcene, â-ocimene, â-thujone by 6.03 , $3.251,2.093,33.73,7.573,15.041$, and $8.00 \%$ respectively. The earlier reported essential oil from A. nilagirica syn. A. vulgaris contains camphor, â-caryophyllene, Dgermacrene, á-humulene, 1,8-cineole, â-eudesmol, borneol, artemisia alcohol, camphene, á-gurjunene, pcymene, terpinene-4-ol, á-pinene, á-phellandrene, äcarene, trans-isoelemicin, lyratol, ã-elemene, (-)-linalool, thujone, azulene, thujyl alcohol, fernenol, stigmasterol, sitosterol, amyrin and its acetate (Haider et al., 2007; Uniyal et al., 1985 and Aboutabl et al., 1997) of which some are either absent or found as minor constituents. Some antifungal constituents have also been reported from the plant (Shafi et al., 2004). The essential oil of $A$. nilagirica was found to possess complete antidermatophytic activity by the poisoned food technique (Kishore et al., 2001).

Various parts of $A$. capillaris lead to isolation of $\mathrm{p}$ cymene, 5-phenyl-1,3-diyne, dehydrofalcarinone, dehydrofacarinol, aromatic C-11-C-13 acetylenes, aesculetin dimethylether, capillene, aliphatic C-17 acetylene (Harada and Iwasaki, 1982) 62 -O-caffeoyl-phydroxyacetophenone-4-O-Â-D-glucopyranoside and 6amino-9-[1-(3,4-dihydroxyphenyl)ethyl]-9H-purine (Ma et al., 2008), 6,7-dimethyl esculetin (Aburada et al., 1976), capillarisin (Komiya et al., 1975), artemisidin A, artemicapins A-D (Shung et al., 2001). The growing buds contain ã-terpinene, caryophyllene, capillin, capillacin, methyleugenol, curcumene and bornyl acetate as the minor components which showed antifeeding activity to the larvae of cabbage butterfly (Yano, 1987). From the stalk and leaves, the major constituents were capillen, $\stackrel{\mathrm{a}-}{-}$ cadinene, á-thujone, á-humulene and borneol whereas azulene identified as rare constituent (Miyazawa and Kameoka, 1977). The methanolic extract of aerial part from A. capillaris showed antimutagenic activity (Park et al., 1996). A. capillaris has also been reported for cytoprotective and antioxidant activity (Hong et al., 2007; Seo et al., 2003). Infusions of the buds, stems and leaves of $A$. capillaris have been used in Chinese traditional medicine since antiquity as a cholagogic, antipyretic, anti- 
inflammatory and diuretic purposes and in the treatment of jaundice (Tang and Eisenbrand, 1992; Han et al., 2006; Han et al., 2005; Jang et al., 2005; Hong et al., 2004 and Hu et al., 2000). A group of coumarins and flavonol glycosides have also been reported from the inflorescence of A. capillaris (Yamahara et al., 1989 and Fakeya et al., 1976).

Essential oils are generally complex mixtures of compounds, and potential synergistic and antagonistic effects should be taken into account when evaluating the biological activities of essential oils (Brenda et al., 2007). The findings showed a considerable quantitative and qualitative difference between essential oil compositions of A. nilagirica and A. capillaris. These findings showed promising and noticeable variations in the concentrations of their constituents. The constituents of these oils have been found to interfere with respiration and electron transport in a variety of bacteria. Therefore, these oils can be used for food preservation and cosmetic preparations. Since both the plants were collected from different region there must be the effect of soil texture in the concentration on the constituents of these species.

\section{ACKNOWLEDGEMENTS}

The authors pay their sincere thanks to UGC New Delhi, India [Grant No. 33-282/2007(SR)], for financial assistance.

\section{REFERENCES}

Aboutabl, E.A., Elazzouny, A.M., and Eidahmy, S.I. (1997). 28th International symposium on essential oils. Eskisehir, Turkey. p. 40.

Aburada, M., Sasaki, H., and Harada, M. (1976). Pharmacological studies of gardeniae fructus II. Contribution of the constituent crude drugs to choleretic activity of "Inchinko-to" in rats. Yakugaku Zasshi, 96: 147-153.

Brenda, S.W., Bansal A., Moriarity, D.M., Takaku S., and Setzer, W.N. (2007). Cytotoxic leaf essential oils from Neotropical Lauraceae: Synergistic effects of essential oil components. Natural Product Communications, 2: 12411244.

Çetin, B., Ozer, H., Çakir, A., Mete, E., Tosun, M., Ozturk, E., Polat, T., and Kandemir, K. (2009). Chemical composition of hydrodistilled essential oil of Artemisia incana (L.) Druce and Antimicrobial Activity against Foodborne Microorganisms. Chemistry and Biodiversity, 6: 2302-2310.

Fakeya, K., Yoshitomo, N., and Haruji, O. (1976). Studies on 'Inchinko' II. Studies on the compounds related to capillarisin and flavonoids. Yakugaku Zasshi, 96: 855-862.

Gaur, R.D. (1999). Flora of District Garhwal North West Himalaya (With ethno botanical notes), 1st ed. (p. 557558). Trans Media, Srinagar Garhwal, India.

Gilemeister, E., and Hoffman, F. (1961). Die aethorischen ole, 4th ed., vol. 7, (p. 733). Academic Verlag. Berlin.

Haider, F., Naqvi, A.A., and Bagchi, G.D. (2007). Oil constituents of Artemisia nilagirica var. septentrionalis during different growth phases at subtropical conditions of North Indian plains. Journal of Essential Oil Research, 19: 57.

Han, J., Zhao, Y.L., Shan, L.M., Huang, F.J., and Xiao, X.H. (2005). An experiment on standardized cell culture assay in assessing the activities of composite Artemisia Capillaris tablets against hepatitis B virus replication in vitro. Chinese Journal of Integrative Medicine, 11: 54-56.

Han, K.H., Jeon, Y.J., Athukorala, Y., Choi, K.D., Kim, C.J., Cho, J.K., Sekikawa, M., and Lee, C.H. (2006). A water extract of Artemisia capillaris prevents 2,2'-azobis(2amidinopropane) dihydrochloride-induced liver damage in rats. Journal of Medicinal Food, 9: 342-347.

Harada, R., and Iwasaki, M. (1982). Volatile components of Artemisia capillaris. Phytochemistry, 21: 2009-2011.

Hong, J.H., Lee, J.W., Park, J.H., and Lee, I.S. (2007). Antioxidative and cytoprotective effects of Artemisia capillaris fractions. BioFactor, 31: 43-53.

Hong, S.H., Seo, S.H., Lee, J.H., and Choi, B.T. (2004). The aqueous extract from Artemisia capillaris Thunb. inhibits lipopolysaccharide-induced inflammatory response through preventing NFkappaB activation in human hepatoma cell line and rat liver. International Journal of Molecular Medicine, 13: 717-720.

Hu, Y.Q., Tan, R.X., Chu, M.Y., and Zhou, J. (2000). Apoptosis in human hepatoma cell line SMMC-7721 induced by watersoluble macromolecular components of Artemisia capillaris Thunberg. Japanese Journal of Cancer Research, 91: 113117.

Jaime A. Teixeira da Silva. (2004). Mining the essential oils of the Anthemideae . African Journal of Biotechnology, 3: 706720.

Jang, S., Kim, Y.J., Lee, W.Y., Kwak, K.C., Baek, S.H., Kwak, G.B., Yun, Y.G., and Chai, K.Y. (2005). Scoparone from Artemisia capillaris inhibits the release of inflammatory mediators in RAW 264.7 cells upon stimulation cells by interferon-gamma Plus LPS. Archives of Pharmacal Research, 28: 203-208.

Juteau, F., Bessiere, J.M., Masotti, V., and Viana, J. (2002). Composition, characterization of the essential oil of Artemisia compestris ver. glutinosa. Biochemical Systematics and Ecology, 30: 1065-1070.

Kishore, N., Dubey, N.K., and Chansouria, J.P.N. (2001). Antimycotic activity of the essential oil of Artemisia nilagirica. Flavour and Fragrance Journal, 16: 61-63.

Komiya, T., Tsukui, M., and Oshio, H. (1975). Capillarisin, a constituent from Artemisia capillaris Herba. Chemical and Pharmaceutical Bulletin, 23: 1387-1388.

Ma, H.Y., Sun, Y., Zhou, Y.Z., Hong, M., and Pei, Y.H. (2008). Two new constituents from Artemisia capillaris Thunb. Molecules, 13: 267-271.

Miyazawa, M., and Kameoka, H. (1977). The essential oil of Artemisia capillaris. Phytochemistry, 16, 1054-1057.

Okuno, I., Uchida, K., Kadowaki, M., and Akahori, A. (1981). Choleretic effect of Artemisia capillaris extract in rats. Japanese Journal of Pharmacology, 31: 835-838.

Park, K.Y., Ha, J.O., Yu, Y.B., Lee, J.H. and Park, J.C. (1996). Antimutagenic effect of some Artemesia species. Korean Journal of Pharmacognosy, 27: 96-100.

Ramezani, M., Behravan, J. and Yazdinezhad, A. (2005). 
Chemical composition and antimicrobial activity of the volatile oil of Artemisia khorassanica. from Iran. Pharmaceutical Biology, 42: 599-602.

Rao, R. R. (1994). Biodiversity in India (Floristic aspect), Bishan Singh-Mahendra Pal Singh, Dehradun, India. ISBN: 8121100100.

Saleh, M. A., Belal, M. H. and El-Baroty, G. (2006). Fungicidal activity of Artemisia herba alba asso (Asteraceae). Journal of Environmental Science and Health, Part B, 41: 237-244.

Seo, H.C., Suzuki, M., Kameyama, M.O., Oh, M. J., Kim, H. R., Kim J. H. and Nagata, T. (2003). Extraction and identification of antioxidant components from Artemisia capillaris herba. Plant Foods for Human Nutrition, 58: 112.

Shafi, P.M., Nambiar, M. K. G., Clery, R. A., Sarma, Y. R. and Veena, S. S. (2004). Composition and antifungal activity of oil of Artemisia nilagirica (Clarke) Pamp. Journal of Essential Oil Research, 16: 377-379.

Shung, W. T., Jing, T. Z., Lin, W. P., Wen, L. F., Yin, L. C., Ming, T. C. and Hsiung, L. K. (2001). New constituents and antiplatelet aggregation and anti-HIV principles of Artemisia capillaris. Bioorganic and Medicinal Chemistry, 9: 77-83.

Tang, W. and Eisenbrand, G. (1992). Chinese drugs of plant origin, chemistry, phamacology and use in traditional and modern medicine (p. 179). Springer Verlag, New York.

Uniyal, G. C., Singh A. K., Shah, N.C. and Naqvi, A. A. (1985) Volatile constituents of A. nilagirica. Planta Medica, 51: $457-$ 458.

Yamahara, J., Kobayashi, G., Matsuda, H., Katayama, T. and Fujimura, H. (1989). The effect of scoparone, a coumarin derivative isolated from the chinese crude drug Artemisiae capillaris flos, on the heart. Chemical Pharmaceutical Bulletin, 37: 1279-1299.

Yano, K. (1987). Minor components from growing buds of Artemisia capillaris that act as insect antifeedants. Journal of Agricultural and Food Chemistry, 35: 889-891. 